\title{
TECHNO-ECONOMIC APPROACH TO SOLAR ENERGY SYSTEMS ONBOARD MARINE VEHICLES
}

\author{
Ahmed A. Salem ${ }^{1)}$ \\ Ibrahim Sadek Seddiek ${ }^{2)}$ \\ 1) Department of Marine Engineering, Faculty of Maritime Studies, King \\ Abdulaziz University, Jeddah, Saudi Arabia \\ 2) Marine Engineering Technology Department, Arab Academy for \\ Science,Technology \& Maritime Transport, Alexandria, Egypt
}

\begin{abstract}
The world is facing the challenge of continuously increasing energy consumption. At the same time, the energy resources are getting scarcer. Despite a sudden significant drop of fuel prices worldwide, research activities that focus on reducing the dependence on fossil fuels as a traditional source of energy still have the preference in the field of shipping industry. The use of clean and renewable energies, such as solar energy for instance, is proposed as a method to improve the ship efficiency. Ships can get the benefits from solar energy due to the fact that most of their upper decks are always exposed to the Sun, especially in sunny water regions. The present paper discusses the effectiveness and challenges of installing solar panels for auxiliary power production on board a ship. As a case study, the research evaluates both economic and environmental benefits resulting from implementing such concept aboard a research vessel.
\end{abstract}

Keywords: Environmental issues, fuel saving, solar energy, photovoltaic cells, ship emissions

\section{INTRODUCTION}

The insight of scientific improvements, augmentation of community awareness of environmental issues, and the economic climate have accelerated and continued the interest in renewable sources of energy worldwide. The start of dealing with renewable resources requires major changes in our energy infrastructure. The availability of Wind, Water, and Sunlight (WWS) energy resources, converted using such devices as wind turbines, concentrated solar plants, solar photovoltaic (PV) power plants, rooftop PV systems, geothermal power plants, hydroelectric power plants and tidal turbines resources, can power a 2030 WWS world that uses electricity and electrolytic hydrogen for all purposes. Such WWS infrastructure may lead to a reduction of the world power demand by about $30 \%$ of its current value (Jacobson and Delucchi, 2011). Although there is a high degree of preference for replacing fossil energy sources by their renewable equivalents aboard ships; the study of developing renewable infrastructures for marine transportation is still in its first steps (Mekhilef et al., 2011). Unfortunately, marine application of the majority of renewable energy sources still pose a great problem (Glykas et al., 2010), but among various types of them, solar energy has the priority to be applied aboard ships (Hua et al., 2008).
If we look closer around us, we will find that any source of energy, even fossil fuels, is mainly based on the Sun. Plants depend on the Sun to make food, animals eat the plants, and both of them end up becoming key ingredients for fossil fuels. Without the Sun, nothing would exist on this planet (McLamb, 2011). The Sun is a remarkable source of renewable energy in the form of heat and light which can be converted into electricity. However, despite their extended use at main land applications, the presence of solar energy systems in modern marine technology remains limited. They mainly work as suppliers to small lighthouses, buoys, and chargers for batteries of small sailing yachts. However, the rising transport expenses due to fuel prices, the increasing restrictions of Carbon dioxide $\left(\mathrm{CO}_{2}\right)$ and Nitrogen oxides $\left(\mathrm{NO}_{\mathrm{x}}\right)$ emissions due to new ecological policies, and, finally, the general need for more eco-friendly transportation modes are the reasons that force marine companies to re-examine systematic use of PV systems on large vessels (Kobougias et al., 2013).

The fundamental aim of this paper is to highlight various solar power units that could be utilised aboard ships. In addition, the paper discusses and assesses the effectiveness of using solar energy as an auxiliary power supply in order to reduce fuel consumption and its emissions. Furthermore, the paper studies certain challenges, as well as economic and 
environmental issues concerning possible applications of this concept aboard a hydrographic surveying research vessel working in the Red Sea water region.

\section{BENEFITS AND BARRIERS OF SOLAR ENERGY AGAINST CONVENTIONAL MARINE POWER PLANTS}

From the view point of availability, most of conventional marine power plants depend on fossil fuels, which are expected to be exhausted during the few coming decades, while solar energy is considered a renewable and continuous source of energy that is supplied by the Sun to everywhere on the Earth (Seddiek and Elgohary, 2014). Undoubtedly, the conventional marine fuels have worked effectively over the past decades, especially with respect to safety, performance and adaptability. But due to huge amounts of harmful emissions from ships, strict emission regulations were introduced by the International Maritime Organization (IMO) during the last few years to overcome this problem (Seddiek, 2015). On the other side, solar energy produces no emissions, i.e., it is environmentally safe. Moreover, unlike conventional marine power plants; solar energy systems are noiseless, which is an important factor especially on passenger ships. Lastly, solar energy systems can act as an ideal power source, independent of the ship's electromechanical systems (Hussein and Ahmed, 2014).

Despite the aforementioned benefits, low efficiency of the solar power system is a main barrier that limits its widespread use. The average thermal efficiency of a conventional marine engine is about 40 per cent, while the solar PV system efficiency is about 15 to 20 per cent (de Castro Nóbrega and Rössling, 2012). Performance restrictions on solar PV system components such as batteries, inverters, and other power conditioning systems are another barrier. Additionally, since the solar power system is always exposed to the weather, water may seep through tiny cracks in the glass of the PV unit, especially during rainy season, causing dust and algalgrowth to accumulate along the lower section of the panels. All this constitutes major problems in the operation of PV systems. Furthermore, low density of the produced power makes it difficult to depend on solar power as a main source of electric power aboard ships (Mahmud et al., 2014).

\section{ESSENTIAL REQUIREMENTS FOR A SUCCESSFUL SOLAR-POWERED SHIP}

Studying the applicability of solar power systems aboard ships indicates that there are some factors that may affect this applicability. These factors include: (1) availability of high solar radiation along the ship route, (2) existence of adequate deck area exposed to the Sun, (3) availability of a suitable grid-connected PV solar power system, (4) techno-economic selection of available solar panels, and (5) scientific preparation of the system layout.

\section{SOLAR RADIATION DISTRIBUTION}

Data on the solar radiation distribution in a given water region are of vital importance when assessing the possibility of using any solar energy system as a power source in that region. Such data are prerequisites for the design of any solar power conversion system. The solar radiation received at the Earth's surface is subject to many years of observation (possibly not less than 20 years) that must be attained in order to get a precise estimation of the long-term distribution and availability. There are many places in the developing countries that do not have necessary facilities for accurate and continuous measurements of solar radiation, hence it is necessary to use some experimental methods based on easily-measured meteorological parameters such as: relative humidity, temperature, duration of bright sunshine, rainfall periods and cloudiness (Paulescu et al., 2012). The long-term average of the annual sum of radiation worldwide ranges from 700 to $2700 \mathrm{~kW} . \mathrm{hr} / \mathrm{m}^{2}$ while the daily sum is from 2.0 to $7.5 \mathrm{~kW} . \mathrm{hr} / \mathrm{m}^{2}$. In particular, it is found from the radiation map of Arab countries that the annual and daily sums of radiation range from 1600 to $2400 \mathrm{~kW} . \mathrm{hr} / \mathrm{m}^{2}$ and from 4.4 to $6.6 \mathrm{~kW} . \mathrm{hr} / \mathrm{m}^{2}$, respectively, as shown in Figure 1.

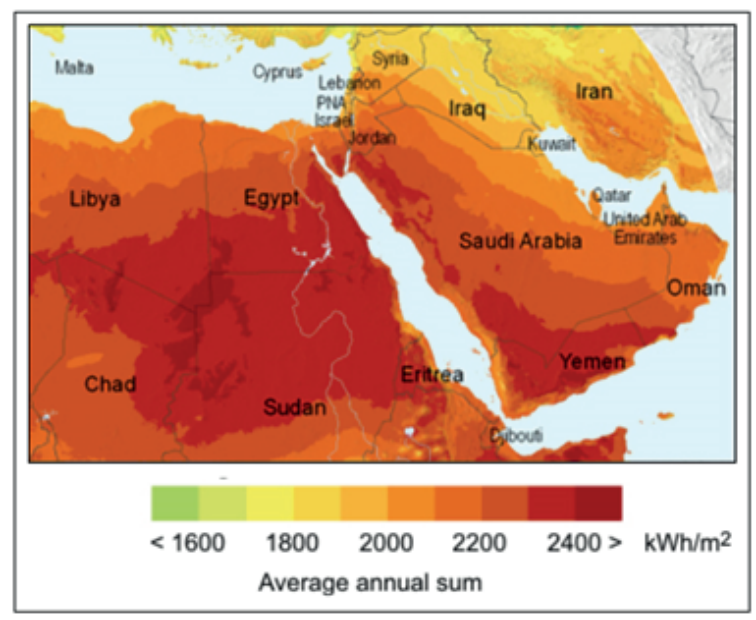

Figure 1: World Solar radiation distribution (Paulescu et al., 2012)

\section{SUN-EXPOSED DECK AREA}

The available sun-exposed deck area aboard a ship plays a great role in the amount of absorbed solar energy. The available area is a function of several factors, such as ship type, ship dimensions, and deck machinery arrangement. The larger the number of solar panels that can be installed, the more sunlight they can collect and, consequently, the faster the solar energy is converted into electricity that can be stored in batteries. Large deck area is also important in other situations, such as cloud cover, or low-angled and lowintensity light in winter. The charging time can vary from 4 to 16 hours of sunlight for one battery, depending on the surface area and light conditions.

Solar energy can be calculated according to the geographical position, solar panel area, and solar panel efficiency. Generally, the amount of solar energy which can be absorbed is estimated 
as follows:

$$
\text { Amount of Solar Energy }=A S E * P . A * \mu
$$

where, (ASE) is the average solar energy per unit area $(\mathrm{kW} /$ $\left.\mathrm{m}^{2}\right),(\mathrm{P} . \mathrm{A})$ is the solar panel area $\left(\mathrm{m}^{2}\right)$, and $(\mu)$ is the solar panel efficiency.

\section{GRID-CONNECTED PV SOLAR POWER SYSTEM}

A grid-connected PV solar power system consists mainly of solar panels, inverter, battery bank, and other necessary electric devices. Figure 2 describes a simple model of a grid-connected PV system which can be installed on board a ship. As shown in the figure, the multiple solar panels 1 are connected together to make up a solar array 2 which is responsible for producing DC (direct current).

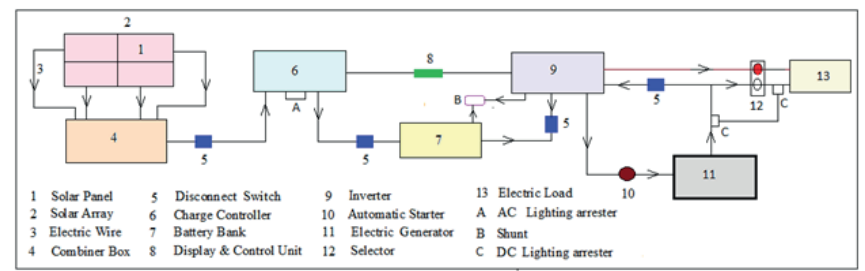

Figure 2: Simple model of grid-connected PV solar power system that can be installed on board a ship

It is noteworthy that the number of solar panels that can be used depends on the storage capacity of the used batteries. The produced DC is then transferred to the combiner box 4 via electric wires 3 . The electric current flows across the disconnect switch 5 to the charge controller 6 , which controls the current coming from the solar panels and prevents batteries from overcharging (SolarGIS, 2015). The electricity then goes to multiple batteries composing the battery bank 7 . The batteries use and store DC. They have low voltage output, usually in the range of 12-24 volts. As most of the appliances on board ships operate on $220 \mathrm{~V}$ AC, the inverter 7 is needed in the system to convert DC into AC. The shunt $\mathrm{B}$ is used to measure the electric current passing between the battery bank 7 and the inverter 9. The produced AC is supplied to the designated electric consumers 13, to provide lighting, for instance. Once the quantity of solar energy becomes low; the automatic Genset starter 10 is activated to start up the electric diesel generator 11. The selector 12 is used to switch between the current coming from the inverter and that supplied by the generator.

\section{IMPACT OF THE WEIGHT OF SOLAR ENERGY SYSTEM ON SHIP STABILITY}

There is no doubt that adding extra weight aboard the existing ship will result in certain location changes of its centre of gravity, which will probably affect its stability. It should be noted here that the added weight of the solar panels, which need to be placed at the upper decks exposed to the Sun, will result in a vertically upward shift in the ship's centre of gravity. However, at the same time the heaviest component of the solar power system, which is the battery bank, is usually secured properly at the bottom of the ship, near the keel, which brings down the ship's centre of gravity. All this is expected to result in negligible effect on the ship's intact stability (Rolland, 2013); (Moustafa and El-bokl, 2014); (Santosa and Utama, 2014), and (Raj, 2014).

\section{POTENTIAL FOR MARINE APPLICATIONS OF SOLAR POWER SYSTEMS}

In order to study the applicability of solar power system aboard a ship, a great amount of important information needs to be collected and estimated. Examples of such data that need to be collected and/or estimated include: ship's principle particulars, deck layouts, fuel consumption, the initial, operating and maintenance costs of the diesel generator, the required solar power for feeding batteries, market prices of solar panels, among others. The consumed auxiliary power of the vessel should also be taken into consideration in order to determine the suitable number of solar panels that are capable of supplying the amount of power similar to that supplied by the marine diesel generator. In the reported project, solar panels are used to supply $24 \mathrm{~V}$ DC power to the battery bank, from which it is used to run electronic equipment such as alarms, lights, emergency lights, radio navigational aids, navigational lights, and other emergency loads on board the ship. The collected data are used to analyse the cost of the implemented solar power system and then compare it to the cost of the consumed fuel from the Gensets. The environmental impact of the implemented solar power system is also analysed.

\section{ECONOMIC ANALYSIS}

The economic aspect is one of the main indicators that are to be taken as the evidence of possible benefits from installing the solar power system aboard the ship as auxiliary power supply for some electrical instruments in a way to reduce the fossil fuel consumption and hence save its cost and avoid emissions. The annual net cost savings resulting from implementing the solar power aboard the ship can be estimated from the following formula:

\section{Annual Net Cost Savings $=A A E P C-A A C$}

The AAEPC is the on board Annual Auxiliary Engine Power generation Cost for the same electric load, either during sailing or at berth. The AAEPC (in US\$/year) is the sum of fuel cost, maintenance cost, and operating cost, and it is calculated from the following equation:

$$
A A E P C=P_{a u x}, t_{c}, s f c \cdot f_{c} \cdot 10^{-6}+\sum_{a=1}^{u-y} C_{a} M_{a}+\sum_{b=1}^{D=w} C_{b} o_{b}
$$

where, $\mathrm{P}_{\text {aux }}$ is the Diesel engine power $(\mathrm{kW})$, $\mathrm{t}_{\mathrm{c}}$ is the time of connection to batteries (hr/year), sfc is the specific Diesel fuel oil consumption ( $\mathrm{g} / \mathrm{kW} . \mathrm{hr}$ ), $\mathrm{f}_{\mathrm{c}}$ is the Diesel fuel oil cost (US\$/ tonne), $\mathrm{C}_{\mathrm{a}} \mathrm{M}_{\mathrm{a}}$ is the auxiliary onboard engine maintenance cost (US\$/year), and $\mathrm{C}_{\mathrm{b}} \mathrm{O}_{\mathrm{b}}$ is the auxiliary onboard engine operating 
cost (US\$/year). Symbols y and w refer to maintenance and operating items, respectively.

The AAC is the Annual Average Cost of the implemented solar energy system, which can be estimated from the following equation:

$$
A A C=T U C \times C R F
$$

where TUC is the Total Unit Cost of the solar energy system (US\$), and CRF is the Capital Recovery Factor, given by:

$$
C R F=\frac{i(1+i)^{N}}{(1+i)^{N}-1}
$$

Here, $\mathrm{N}$ is the expected number of years of ship operation after implementing the solar panel system, and $i$ is the annual interest rate.

The [TUC] of any solar energy system depends on three main variables, which are: the initial cost, the operating cost, and the maintenance cost. The initial cost includes, in addition to the purchase and installation cost of the system, various sub-systems necessary for its effective operation. The operating and maintenance costs are difficult to quantify because they depend on a large number of variables, such as local labour cost, life-time of the equipment, and operating time. Based on the data collected from actual projects utilising the same solar panels, and on quotations obtained from solar panel manufacturers; the value of initial, operating and maintenance costs can be estimated from the following equation (Moustafa and El-bokl, 2014); (Sulaiman et al., 2011); (Spagnoloet al., 2012), and (Ren et al., 2013):

$$
T U C=S P_{C C} \cdot N_{m}\left[1+i n s_{c p}\right]+\sum_{a=1}^{a=i} P G_{a}+\sum_{c=1}^{c=j} O \& M_{c}
$$

where, $\mathrm{SP}_{\mathrm{CC}}$ is the cost of one solar panel in (US\$); $\mathrm{N}_{\mathrm{m}}$ is the number of solar panel modules; ins is the installation cost percentage; $\mathrm{PG}_{\mathrm{a}}$ is the power grid system cost in (US\$); O\&M is the operating and maintenance cost in (US\$); $\mathrm{i}$ is the total number of components of the power grid system, and $j$ is the total number of various operating and maintenance cost items.

The costs of both the solar array and the power grid need to be estimated separately, because they are independent of the system specification, as follows:

\section{Estimation of solar array cost}

The cost of solar array depends mainly on the number of solar panels $\left(\mathrm{N}_{\mathrm{m}}\right)$. This work presents two different methods for the calculation of the number of solar panels, which depend on the stage of applying solar energy concept aboard. In case of new build ships, $\mathrm{N}_{\mathrm{m}}$ is proportional to the required electric load to be covered. The calculations presented in (Soufi et al., 2013), and (Wang and Nehrir, 2008) can be used to determine the number of solar modules which will be able to provide the required electricity, as follows:

$$
N_{m}=\frac{E_{l} * P S I * \mu_{p v}}{G_{a v} * T C F * \mu_{T} * P V_{p p}}
$$

$$
\mu_{T}=\mu_{P V} * \mu_{i n v} * \mu_{b}
$$

where $\mathrm{E}_{1}$ is the average daily required electric load in (Watt/ day), PSI is the peak solar intensity at the Earth's surface (kW/ $\left.\mathrm{m}^{2}\right), \mu_{\mathrm{PV}}$ is the PV (panel) efficiency, which is about $0.15-0.20$ per cent (Kobougias et al., 2013), and (Mahmud et al., 2014), $\mathrm{G}_{\mathrm{av}}$ is the average solar energy input per day, TCF is the temperature correction factor, which is about 0.8 (Soufi et al., 2013), $\mathrm{PV}_{\mathrm{pp}}$ is the maximum power of the selected solar panel, $\mu_{\mathrm{T}}$ is the overall solar panel effeciency, $\mu_{\mathrm{inv}}$ is the inverter efficiency, which is up to $0.8-0.85$ per cent (Ahmad and Khan, 2012), and $\mu_{b}$ is the battery efficiency, which is about $70-80$ per cent (Patil et al., 2013).

For the already existing ships, $\mathrm{N}_{\mathrm{m}}$ depends on the available area exposed to the Sun and suitable for solar array installation $\left(\mathrm{A}_{\mathrm{av}}\right)$ in $\left(\mathrm{m}^{2}\right)$ as well as on the selected solar panel area available in the market $\left(\mathrm{A}_{\mathrm{SP}}\right)$ in $\left(\mathrm{m}^{2}\right)$. It can be calculated as follows:

$$
N_{m}=\frac{A_{a v}}{A_{S P}}
$$

Consequently, the electric load which can be provided by the solar energy system $\left(\mathrm{E}_{\mathrm{SE}}\right)$ in (Watt.hr/day) may be formulated as follows:

$$
E_{S E}=P V_{P P} * N_{m} * \mu_{B} * \mu_{i n v} * T_{S}
$$

where, $\mathrm{T}_{\mathrm{S}}$ is the average time during which the solar array is expected to be subjected to solar energy.

Estimation of power grid cost

The cost of power grid system includes the cost of batteries, inverter, and charge controller. The cost of batteries can be estimated as follows:

$$
\text { Batteries cost }=N_{B} * B_{C}
$$

where $B_{C}$ is the cost of one battery, $N_{B}$ is the total number of batteries needed to supply the required current, which may be calculated as presented in (Moustafa and El-bokl, 2014), and (Bhatt and Verma, 2014) as follows:

$$
N_{B}=\frac{E * N_{d}}{V_{B} * B_{c a p} * D o D}
$$

Here $\mathrm{E}$ is the electric load provided by the solar system depending on the ship's situation, i.e. already existing or newly built, $\mathrm{N}_{\mathrm{d}}$ is the expected number of days without sunshine, $\mathrm{V}_{B}$ in (volts) and $\mathrm{B}_{\text {cap }}$ in (A.hr) are the voltage and capacity of the selected battery, respectively, and DoD is the battery depth of discharge. The costs of inverter and charge controller are taken as specific power in (US\$/Watt) (Hussein and Ahmed, 2014), and (Moustafa and El-bokl, 2014).

Finally, the annual operation and maintenance (O\&M) cost of the system can be either estimated according to data collected from the established units, companies and catalogues, or taken as a percentage of the capital cost and interest charge (Bhatt and Verma, 2014). 


\section{ENVIRONMENTAL ANALYSIS}

The amount of emissions released from the ship's diesel generator depends mainly on the emission factors of the used fuel, which vary largely among different engines and fuels. On the other side, the emissions released by the Solar PV system are considered equal to zero as there is no burned fuel. To evaluate gains of using the concept of Solar PV system as a green alternative to the auxiliary diesel engines, it is very important to estimate the quantity of the exhaust gases emitted from the auxiliary diesel engines. These amounts are estimated during the ship's sailing and berthing. The quantity of emissions depends mainly on the main emission factors, the consumed electric load, and the working hours. Table 1 summarizes the main emission factors of the diesel generator (Seddiek et al., 2013).

Table 1: Summary of main emissions factors of Diesel generator

\begin{tabular}{|c|c|c|c|c|c|c|}
\hline Emission Gases & $\mathrm{CO}_{2}$ & $\mathrm{CO}$ & $\mathrm{NOx}$ & $P M_{10}$ & $S O x$ & $H C$ \\
\hline Emission Factor $(\mathbf{g} / \mathbf{k} \boldsymbol{W} . \boldsymbol{h})$ & 698 & 1.68 & 13.43 & 0.55 & 2.56 & 0.53 \\
\hline
\end{tabular}

As the solar energy system has zero emissions, the amount of emissions that can be deducted as a result of implementing the solar energy system aboard ships $\left(\mathrm{E}_{\text {deduct }}\right)$ can be expressed as follows:

$$
E_{\text {deduct }}=E_{f} \times t_{s} \times P
$$

where, $\mathrm{E}_{\mathrm{f}}$ is the emission factor in $(\mathrm{g} / \mathrm{kWh})$. and $\mathrm{P}$ is the power saved when using the solar power system in $(\mathrm{kW})$.

\section{CASE STUDY}

To demonstrate the use of the abovementioned equations to study the feasibility of implementing the solar energy aboard an existing vessel, the authors have selected the research boat "Al-Azizi" owned by King Abdulaziz University and working for hydrographic surveying in the Red Sea water region. The boat has a flat-top deck structure that increases the area available for installing the PV solar array. Figure 3 shows a photo of this boat, while Table 2 collates its characteristics.

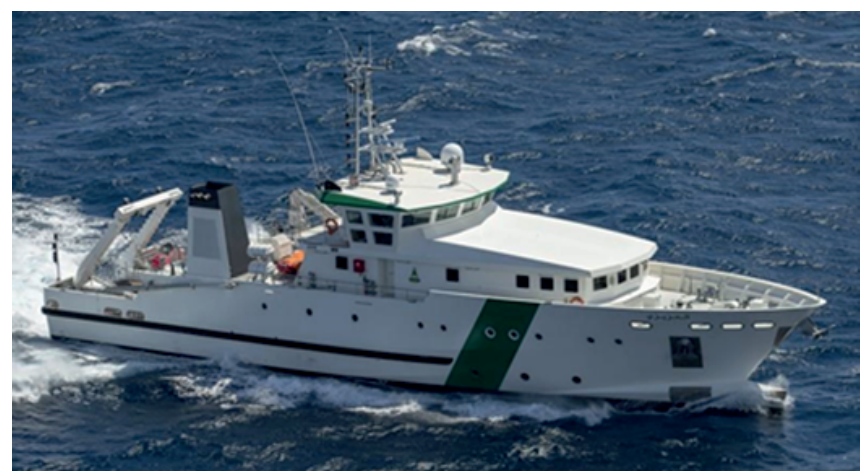

Figure 3: The hydrographic surveying research boat "Al-Azizi"
In the present case study the solar panels are expected to be used to supply power for lights, alarms, emergency lights, radio navigational aids, navigational lights and emergency loads. Although they consume small power, these equipment elements are very essential for boat operation. With the support of solar panels, the power stored in the batteries is expected to be available to operate these instruments even when the Gensets are broken down. For any cloudy or emergency condition, a backup power system integrated with the PV cell should drive the boat to make the system more secured.

Table 2: Characteristics of the research boat

\begin{tabular}{l|c}
\cline { 2 - 2 } Ship Type & Research Boat \\
\hline Maximum speed & $14 \mathrm{knots}$ \\
\hline Transit speed (medium load) & $12 \mathrm{knots}$ \\
\hline Length overall & $43.1 \mathrm{~m}$ \\
\hline Beam & $9.5 \mathrm{~m}$ \\
\hline Draft at full load & $3.2 \mathrm{~m}$ \\
\hline Depth & $3.8 \mathrm{~m}$ \\
\hline Main generator & $11 \mathrm{kWh}$ \\
\hline $\begin{array}{l}\text { Average electrical power required during the } \\
\text { cruise }\end{array}$ & $5 \mathrm{kWh}$ \\
\hline $\begin{array}{l}\text { Average electrical power required during the } \\
\text { berthing }\end{array}$ & $90 \mathrm{~m}^{2}$ \\
\hline Area available for solar array installation (Aav) & $8 \mathrm{hrs}$ \\
\hline Average time of exposition to the Sun &
\end{tabular}

\section{SELECTED SOLAR SYSTEM}

As the present case study refers to the existing vessel; the amount of electric load provided by the solar system using multi-crystal PV solar panel model (KD260GX-LFB2) can be estimated using the deck area exposed to the Sun which is available for solar array installation aboard the vessel. The specifications of the selected solar panel are shown in Table 3.

Table 3: Solar panel specifications

\begin{tabular}{|l|c|}
\hline Model & KD260GX-LFB2 \\
\hline Size & $166^{*} 99 * 4.6 \mathrm{~cm}$ \\
\hline Weight & $20 \mathrm{~kg}$ \\
\hline Power rating $\left(P V_{p p}\right)$ & $260 \mathrm{Watt}$ \\
\hline Open circuit voltage $\left(V_{o c}\right)$ & $38.3 \mathrm{volt}$ \\
\hline Short circuit current $\left(I_{s c}\right)$ & $9.09 \mathrm{Amps}$ \\
\hline Voltage at $P_{\max }\left(V_{m p}\right)$ & $31 \mathrm{volt}$ \\
\hline Current at $P_{\max }\left(I_{m p}\right)$ & $8.39 \mathrm{Amps}$ \\
\hline Solar panel cost & $322 \mathrm{US} \$$ \\
\hline
\end{tabular}

The data related to the selected battery, inverter, and charge controller are listed in Table 4.

The data collected from the hydrographic surveying research vessel regarding the solar system and the fuel prices have been used to estimate both the annual solar system installation cost (AAC) and the annual operating cost of the auxiliary engine, as shown in Figure 4. Giving a period of about 10 years as a life-cycle of the solar energy system, the installation cost is expected to be recovered within the first 3 years, which is a short period compared to the expected ship age. 
Table 4: Characteristics of battery, inverter, and charge controller

\begin{tabular}{|c|c|}
\hline Item & Value \\
\hline $\mathrm{B}_{\text {cap }}$ & $300 \mathrm{Ah}$ \\
\hline $\mathrm{N}_{\mathrm{d}}$ & 2 \\
\hline $\mathrm{DoD}$ & 0.8 \\
\hline $\mathrm{V}_{\mathrm{B}}$ & 12 \\
\hline $\mathrm{M} \& \mathrm{O}$ & $\begin{array}{c}0.5 \% \text { of total } \\
\text { cost }\end{array}$ \\
\hline ins $_{\mathrm{cp}}$ & $10 \%$ \\
\hline
\end{tabular}

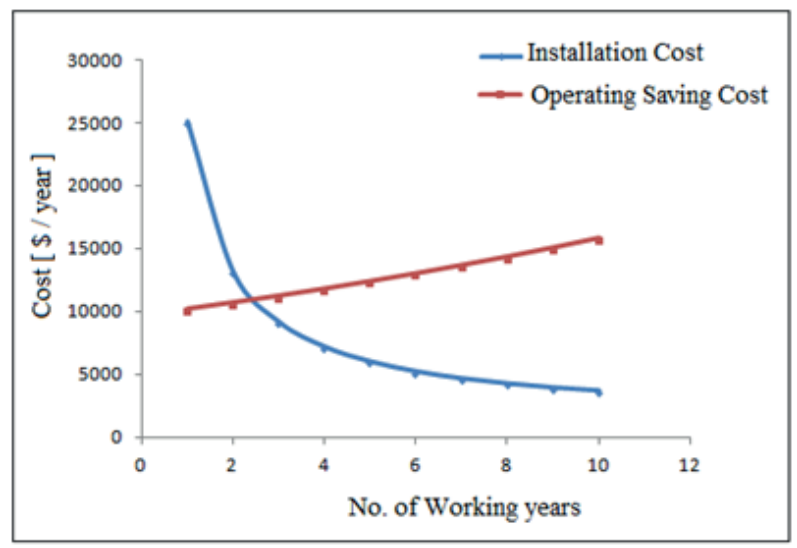

Figure 4: Installation and Operating Costs

Figure 5 presents several scenarios considered in the economic analysis in the case of applying the proposed system on board the research boat "Al-Azizi". It is clear that due to the low cost of fuel inside the Kingdom of Saudi Arabia, the money back period will be longer than if it is applied in another country with higher fuel prices. For a period of 10 working years, the proposed system can achieve a fuel saving cost of about 18500 and 5600 (\$/year) in case of international and local fuel prices, respectively.

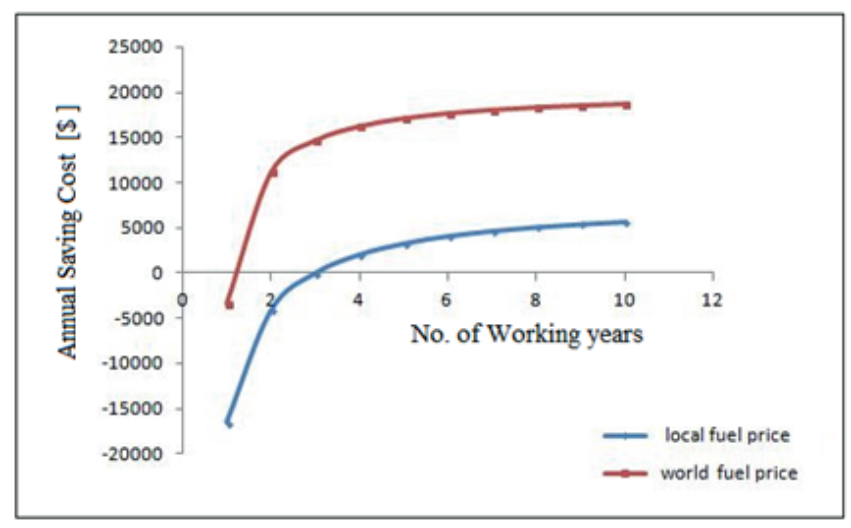

Figure 5: Various scenarios demonstrated in the economic analysis
Figure 6 shows the annual quantities of emission reduction when applying the solar energy concept aboard the research boat. The results show that there is a possibility of achieving a total reduction in ship's emissions of about 21.5 tonnes per year.

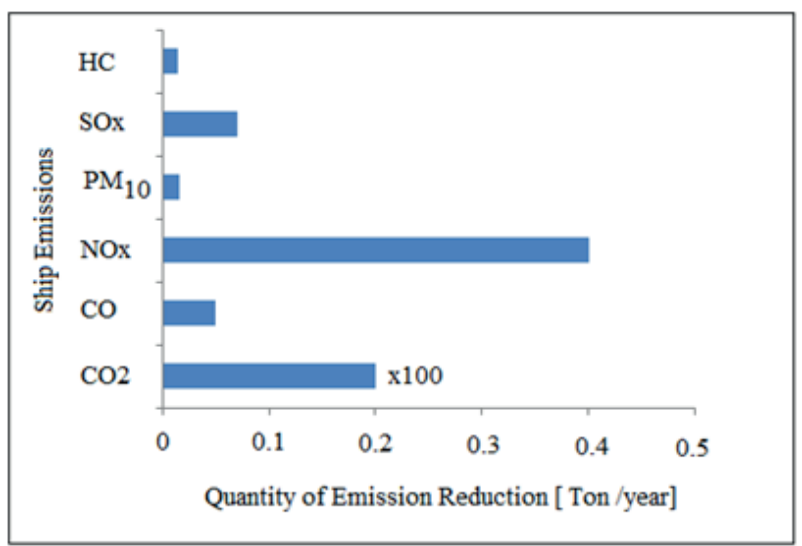

Figure 6: Environmental Benefits of Solar Concept

This amount is valuable in terms of ship's emissions reduction, especially with the new legislations issued by the International Maritime Organization, aiming to apply either Energy Efficiency Design Index (EEDI) or Ship Energy Efficiency Management Plan (SEEMP) for eliminating greenhouse gases. It should be noted that the results regarding both economic and environmental benefits, which are presented in this work, can vary from one boat to another or from one country to another, but there is no doubt that each time the results will be eco-friendly.

\section{CONCLUSIONS}

Besides its domestic uses, solar power can be utilised to supplement the auxiliary power usually produced by the boat's Diesel generator. As a consequence, it will be capable of minimising both air pollution and fuel cost. The PV solar panel appears to be a suitable solar power unit for boats. The present paper shows that until now, there are some challenges that need to be overcome before integrating solar energy on a ship. The sufficient area of the deck space exposed to the Sun is believed to be a major constraint. In addition, more attention should be paid to increase the durability of the PV solar panel through increasing its efficiency and decreasing its cost (perhaps by mass production). As a numerical study, the research boat "Al-Azizi”, owned by King Abdulaziz University and working in the Red Sea water region, was selected as a case study to demonstrate the benefits of the solar power system. The study has revealed that, economically for a period of 10 working years, the proposed system can achieve a fuel saving cost of about 18500 and 5600 (\$/year) in case of international and local fuel prices, respectively. Moreover, the present paper shows that the use of solar energy to contribute to the total energy supply on a ship is a smart beginning for designing an environmentally friendly ship. The results show that there is a possibility of achieving a total reduction in ship's emissions 
of about 21.5 tonnes per year. Finally, despite the prediction of constant fuel prices at a low level, the world's concern regarding ship emissions will accelerate the process of using solar power systems on-board ships in the near future, especially with the new legislations issued by the International Maritime Organization.

\section{ACKNOWLEDGEMENT}

This work was funded by the Deanship of Scientific Research (DSR), King Abdulaziz University, Jeddah, under grant no. (D029-980-1437). The authors, therefore, acknowledge with thanks DSR technical and financial support.

\section{REFERENCES}

1. Ahmad, M., \& Khan, B. H., 2012. Design and evaluation of solar inverter for different power factor loads. Energy and Power Engineering, Vol. 4, No. 5, pp.324-329.

2. Bhatt, P., \& Verma, A., 2014. Design and cost analysis of PV System using nano solar cell. International Journal of Scientific and Research Publications, pp. 1-5.

3. de Castro Nóbrega, J. C., \& Rössling, A., 2012. Development of solar powered boat for maximum energy efficiency. International Conference on Renewable Energies and Power Quality (ICREPQ'12), Santiago de Compostela (Spain), 28th to 30th March, 2012.

4. Hua, J., Wu, Y. H., \& Jin, P. F., 2008. Prospects for renewable energy for seaborne transportation-Taiwan example. Renewable energy, Vol. 33, No. 5, pp. 1056-1063.

5. Hussein, A. W., \& Ahmed, M. W., 2014. Solar Energy: Solution to fuel dilemma. International Journal of Research in Engineering \& Technology, Vol. 2, No. 8, pp. 99-108.

6. Glykas, A., Papaioannou, G., \& Perissakis, S., 2010. Application and cost-benefit analysis of solar hybrid power installation on merchant marine vessels. Ocean Engineering, Vol. 37, No. 7, pp. 592-602.

7. Jacobson, M. Z., \& Delucchi, M. A., 2011. Providing all global energy with wind, water, and solar power, Part I: Technologies, energy resources, quantities and areas of infrastructure, and materials. Energy Policy, Vol. 39, No. 3, pp. 1154-1169.

8. Kobougias, I., Tatakis, E., \& Prousalidis, J., 2013. PV Systems Installed in Marine Vessels: Technologies and Specifications, Hindawi Publishing Corporation, Advances in Power Electronics 2013, Article ID 831560, 8 pages.

9. Mekhilef, S., Saidur, R., \& Safari, A., 2011. A review on solar energy use in industries. Renewable and Sustainable
Energy Reviews, Vol. 15, No. 4, pp. 1777-1790.

10. Mahmud, K., Morsalin, S. \& Khan, M. I., 2014. Design and fabrication of an automated solar boat. International Journal of Advanced Science and Technology, Vol. 64, pp. 31-42.

11. Moustafa, M. M., \& El-bokl, E. E., 2014. Solar energy for River Nile cruisers. Brodogradnja, Vol. 65, No. 2, pp. 6172.

12. McLamb, E., 2011. Fossil Fuels vs. Renewable Energy Resources. Renewable Energy Resources: Energy's Future Today, Ecology Global Network, last modified September 6, 2011. http://www.ecology.com/2011/09/06/fossil-fuelsvsrenewable-energy-resources/.

13. Patil, A. R., Atar, K. D., Potdar, A. A., \& Mudholkar, R. R., 2013. Embedded fuzzy module for battery charger control. International Journal of Advanced Research in Electrical, Electronics and Instrumentation Engineering, Vol. 2, No. 8.

14. Paulescu, M., Paulescu, E., Gravila, P., \& Badescu, V., 2012. Weather modeling and forecasting of PV systems operation. Springer Science \& Business Media, ISBN 978 1-4471-4649-0.

15. Raj, A., 2014. Process for harvesting, storing, and using renewable energy to propel and power boats and ships, and maximize their average speed. U.S. Patent Application $14 / 339,649$.

16. Rolland, L., 2013. Ship design classification for wind and solar energy capture. The 3rd Climate Change Technology Conference (CCTC 2013), Paper Number 1569706561.

17. Ren, L., Diao, Y. M., \& Han, Q., 2013. Economic analysis for solar hybrid power of ocean-going fishing vessels towards low carbon. In Advanced Materials Research, Vol. 608, pp. 169-172.

18. Santosa, P. I., \& Utama, I. K. A. P., 2014. An investigation into hybrid catamaran fishing vessel: combination of Diesel engine, sails and solar panels. IPTEK Journal of Proceedings Series, Series 1, No. 1

19. Seddiek, I. S., \& Elgohary, M. M., 2014. Eco-friendly selection of ship emissions reduction strategies with emphasis on SOx and NOx emissions. International Journal of Naval Architecture and Ocean Engineering, Vol. 6, No. 3, pp.737-748.

20. Seddiek, I., 2015. An overview: environmental and economic strategies for improving quality of ships exhaust gases. Trans RINA, Int J Marit Eng, Vol. 157 (Part A1), pp.53-64. 
21. Seddiek, I. S., Mosleh, M. A., \& Banawan, A. A., 2013. Fuel saving and emissions cut through shore-side power concept for high-speed crafts at the red sea in Egypt. Journal of Marine Science and Application, Vol. 12, No. 4, pp. $463-472$

22. SolarGIS, 2015. New Web-Based Service Offering Solar Radiation Data and PV Simulation Tools for Europe, North Africa and Middle East. http//solargis.info, (accessed 10/05/2015).

23. Sulaiman, O., Aron, H., Saharuddin, A. H., Nik, W. W., Kader, A. S. A., \& Ahmad, M. F., 2011. Techno economic study of potential using solar energy as a supporting power supply for Diesel engine for landing craft. International Journal of Business and Social Sciences, Vol. 2, No. 1.

24. Spagnolo, G. S., Papalillo, D., Martocchia, A., \& Makary, G., 2012. Solar-electric boat. Journal of Transportation Technologies, Vol. 2, No. 2, pp.144-149.

25. Soufi, A., Chermitti, A., \& Bibi Triki, N., 2013. Sizing and optimization of a livestock shelters solar standalone power system. International Journal of Computer Applications, Vol. 71, No. 4, pp. 40-47.

26. Wang, C., \& Nehrir, M. H., 2008. Power management of a stand-alone wind/photovoltaic/fuel cell energy system. Energy Conversion, IEEE Transactions on, Vol. 23, No. 3, pp. 957-967.

\section{CONTACT WITH THE AUTHOR}

Ibrahim Sadek Seddiek

Marine Engineering Technology Department Arab Academy for Science, Technology \& Maritime Transport,

Alexandria

EGYPT 